\title{
Protestant-Pluralized
}

\section{How to Understand Interreligious Dialogue in Sweden in Relation to the Socio-Cultural Context}

\author{
Magdalena Nordin \\ Associate Professor, Department of Literature, University of Gothenburg, \\ Gothenburg, Sweden \\ magdalena.nordin@lir.gu.se
}

\begin{abstract}
This article starts by giving an overview on religion in contemporary Sweden and a historic background on IRD-organisations and IRD-activities in the country; followed by a more in-depth description of contemporary IRD, presenting both national and local IRD-organisations and IRD-activities. The article ends with an analysis of how IRD-organisations and IRD-activities relate to the sociocultural context in Sweden, which shows the importance of the increase in religious plurality in Sweden and the Church of Sweden's still dominate position, in the establishment and upholding of IRD-organisations and IRD-activities in the country. Another sociocultural context influencing is the highly secularised Swedish society together with the secular state. This leads both to a delay in establishment of IRD-organizations in Sweden, and later on, for the establishment of these IRD-organizations and for IRD-activities, if the aim of these are less religious and foremost social.
\end{abstract}

\section{Keywords}

interreligious dialogue - Sweden 


\section{Introduction}

Interreligious dialogue (IRD) in Sweden has a short history and the first national interreligious organisation was not established until 2010. There have, however, been various IRD-organisations on a local level before this and IRD-activities on both a local level and a national level have been going on for decades. The explanation for this may be seen in the Swedish socio-cultural context. In The Swiss Metadatabase of Religious Affiliation in Europe (SMRE) ${ }^{1}$ Sweden is, according to religious affiliation, classified as Protestant-Pluralized. This means that Protestantism is the largest 'religion' in the country, but with a share of other religions ranging between $36 \%$ and $59 \%$. However, there are certainly other socio-cultural factors apart from a majority protestant denomination and some religious plurality, influencing IRD in Sweden. The aim of this article is therefore to analyse IRD in relation to the Swedish socio-cultural context, answering the following research question: How can IRD in Sweden be explained by socio-cultural factors?

This will be done by giving an overview on religion in contemporary Sweden, and a description of the historical background of IRD-organisations and IRD-activities in the country, followed by an in-depth description of contemporary IRD, ending up with an analysis of IRD in Sweden in relation to its socio-cultural context. The material for the article is collected through observations, in-depth interviews, semi-structured interviews, and documents, such as protocols, books, reports and websites and former research about IRD. The analysis is mostly to be seen as content analysis, but also in some part as a discourse analysis.

In the article, IRD is understood as organisations that are formalised to primarily be interreligious in their construction; meaning that representatives from different religions are part of the organisation. I also include ecumenical and umbrella organisations as IRD organisations. This has to do with the fact that these have had a long history in Sweden, have in various ways been influential when it comes to IRD and, I would argue, are, if not interreligious, inter-denominational. Other organisations such as the Church of Sweden, a state authority, political parties and educational associations are also included when presenting and analysing IRD in Sweden, because these have had an importance in 'doing' or supporting interreligious dialogue. IRD in the article is also understood as different activities aiming at interreligious dialogue. This aspect of IRD is included to get a broader understanding of IRD

1 Swiss Metadatabase of Religious Affiliation in Europe. 
than the organisations themselves, and to show how IRD in Sweden is initiated and implemented, not only by IRD-organisations, but also as temporary IRD-projects. ${ }^{2}$

Sweden, one of the Scandinavian countries in northern Europe, has 10 million citizens and an area of 450 thousand square kilometres (the fifth largest in area in Europe). It is a parliamentary democracy, a monarchy, and a unitary state, divided into 21 counties and 290 municipalities. The country has been ethnically, and in terms of religion, quite homogenous for a long time in history. In 1999, however, five minorities in Sweden were officially recognised. ${ }^{3}$ In 1952, religious freedom laws were implemented and since 2000 the nation is constitutionally secular. Religious education at schools in Sweden is obligatory, but since 1969 non-confessional. This means that the pupils are taught about religions in school and confessional religious education is taken care of by the religious organisations outside the school system.

For centuries the Evangelical-Lutheran Church of Sweden, the Church of Sweden, has had a dominant position in the country, and in $2019,57 \%$ of the population were still members of the church. This high number of membership has quite recently been even higher, and in the 1970s, 95\% belonged to the church and $85 \%$ of children were baptised in the church (in 2019, $40 \%$ were baptised). ${ }^{4}$ However, foremost due to immigration, the former religious homogeneity in the country has become more pluralistic. This means that aside from the dominant position that the Church of Sweden has, we nowadays find quite many other religious organisations in the country and about 110 are officially recognised as faith communities. ${ }^{5}$ Most of these have been established during the last decennium; the exception from this being the so-called free churches, which refers to the protestant churches that were established

2 See also Ipgrave, Meeting Acting and Talking, pp. 88 et seq.

3 These are Jews, Roma, Sami, Swedish Finns and Tornedalers, which altogether constitutes about 1 million (10 of the population) people, out of which half are Swedish Finns.

4 Statistics, Church of Sweden 2020.

5 This means that they have a different organisational status than other organisations and associations in Sweden. Faith communities also obtain specific privileges such as the right to perform legally valid marriages and to get assistance from the tax authorities in collecting membership fees. To become a recognised faith community they have to be 'an association for religious activities which includes organising worship' (Kammarkollegiet). It also means that they can apply to get state grants that are to be contributed only to religious organisations. The Church of Sweden cannot apply for these grants. 
in Sweden during the 18th to 20th centuries. Today, the free churches have in total of approximately 300,000 members ( $3 \%$ of the population) and are represented in about $75 \%$ of the cities in Sweden. Some of these churches have had a decrease in membership during the latest decades, while others have had an increase (foremost the Pentecostal church). In total, however, they have had a small decline in the share of the population from $4 \%$ in 1970 , to $3 \%$ today. At the same time, larger cities in Sweden have, during the last decade, had a significant growth in establishment of, and membership in, free churches, foremost due to immigration. ${ }^{6}$

Other religious minority organisations in Sweden are Muslim organisations. In total, 233 Muslim communities are registered in Sweden, belonging to seven national Muslim umbrella organisations. ${ }^{7}$ These communities have been established in Sweden mostly due to immigration from the 1970s and onwards; this was also the period when the first mosque in Sweden was constructed. ${ }^{8}$ In total they today host about 170,000 members (1.7\% of the population), and, if we take into consideration every person in Sweden with a Muslim family background, about 500,000 individuals ( $5 \%$ of the population) of the Swedish population may be recognised as Muslim. ${ }^{9}$

There are also various Christian churches in Sweden that have been established and have grown in membership rates in Sweden due to immigration. Approximately 160,000 (1.6\% of the population) Swedes are members of the Orthodox and Eastern churches. When including not only members, but also people with family background in these churches, the number is probably almost double. About one third of these, in total 17 different churches, belong to the Syriac Orthodox Church, and the second largest one is the Serbian Orthodox Church, with 23,000 members. ${ }^{10}$

Until the reformation in the 16th century, Sweden was a Catholic country and the church has since then, mostly in a very marginal position, been part of Swedish society. It was, however, not until the 2oth century that there was a considerable growth in members in the church, also in this case connected to immigration. Today about $120,000(1.2 \%)$ people belong to the Catholic

6 Aronson, Ett nytt karismatiskt landskap; Gärde, Shrinking Religious Communities.

7 Religion i rörelse; there are, however, more than 700 registered organisations that in one way or another are connected to Islam, see Sorgenfrei, Islam i Sverige, p. 223.

8 Nielsen/Otterbeck, Muslims in Western Europe.

9 This comes from a so-called origin proxy-method, which is based on the religious composition of the country of origin and concludes that those who emigrate from the country constitute a religious average.

Religion i rörelse; Nordin, Vad vi vet och inte vet om kristna migranter. 
Church, and the church is to a high degree multinational, multilingual and multi-cultural. ${ }^{11}$

Other much smaller religious organisations can also be found in Sweden. There are, for example, approximately 25,000 Buddhists, 20,000 Jews, 20,000 Jehovah's Witnesses, 10,00o Hindus, 10,00o Mandeans, 8, ooo Mormons, 3,000 Sikhs, 1,000 Bahia adherents and 500 active Scientologists in the country. ${ }^{12}$

Like many Western societies, Swedish society is, however, strongly characterised by secularisation. Religion has an inconspicuous place in Sweden, and religious beliefs and religious practices among the population are declining. Today religion is of importance for about $10 \%$ of the population and about $30 \%$ believe in God. One out of five Swedes pray to God sometimes, and less than every tenth participates regularly in religious gatherings. ${ }^{13}$ After the group of those who are a member of the Church of Sweden (57\%), those who are not affiliated with any religious organisation, so called nones, make up the largest group (about 34\%) in Sweden. Until recently, religion has also not been of any strong interest for state authorities, and other public institutions, and has historically been handled with what can be seen as "pragmatic secularism", meaning that the state has not taken any specific position towards religion. ${ }^{14}$

Sweden has a rather short history of IRD-organisations and IRD-activities. These organisations and activities have also historically been mostly local, and it was not until 2010 that a national IRD-organisation, Interfaith Council in Sweden, was formed. ${ }^{15}$ However, ecumenical and umbrella organisations on a national level can be traced back to the 1930 .

The first ecumenical national organisation, the Swedish Ecumenical Council, was established in 1932. This organisation was reconstructed into the Christian Council of Sweden in 1992, and has since then had an influential role in IRD-activities in Sweden. In 1975, a national umbrella organisation for the Orthodox and Eastern churches came into being, and today 15 churches are part of the organisation. Four years later, in 1979, an interreligious organisation,

\footnotetext{
11 Nordin, Vad vi vet och inte vet om kristna migranter.

12 Religion i rörelse.

13 PEW, How do European Countries Differ in Religious Commitment; Willander, Sveriges religiösa landskap.

14 Bäckström, Religion mellan det privata och det offentliga, pp. 3 o et seq.

15 The Swedish name for the Interfaith Council of Sweden is Sveriges interreligiösa råd, which translated into English, would be Sweden's interreligious council.
} 
but with only two cooperating religious organisations, the Cooperation Council for Jews and Christians, was formed. ${ }^{16}$ In 199o, the first Muslim umbrella organisation, the Muslim Council of Sweden, which involved various Sunni Muslim organisations in Sweden, was established. Today we find seven national Muslim umbrella organisations in Sweden, all of them are part of the organisation Islamic Cooperation Council. ${ }^{17}$ And, in 1992, the so-called free churches in Sweden organised themselves into an umbrella organisation, the Swedish Free Church Council.

Local ecumenical activities started to grow in Sweden in the 196os, and from the mid-196os ecumenical local councils were established..$^{18}$ In the 1970s, these were followed by local IRD-activities with two different religions being represented, primarily involving dialogue between Christians and Jews. During the 1980s, these local cooperations between Christians and Jews expanded and came to include Muslims as well. ${ }^{19}$ Since the 199os, the Church of Sweden has initiated many local IRD-activities mainly including Muslims in Sweden, and about a third of the parishes were engaged in some form of religious dialogue with Muslims in the mid-199os. ${ }^{20}$

\section{4 Contemporary IRD}

Local IRD-organisations and IRD-activities still predominate in Sweden. I will, however, start by presenting some ongoing national IRD-organisations and other influential organisations and authorities related to national IRD-activities, and then give some examples of contemporary local IRD-organisations and IRD-activities in Sweden.

\subsection{Interfaith Council in Sweden}

On a national level, there is, and has been, only one IRD-organisation, and that is the aforementioned Interfaith Council in Sweden. This council was established in 2010 as an initiative of the archbishop of the Church of Sweden and the Christian Council of Sweden. The council is constructed as a network, with a steering group of four people, representing umbrella organisations for Christians, Muslims, Buddhists and Jews, and a council with 19 members; five

\footnotetext{
16 Ahlstrand, Religionsdialog, p. 65 .

17 Gardell, Moskéers och muslimska, p. 5; Sorgenfrei, Islam i Sverige, p. 223.

18 Gustafsson, Lokal ekumenik-symbolakt.

19 Ahlstrand, Religionsdialog, p. 65; Aneer, Dialoger mellan muslimer och kristna, pp. 257-260.

20 Roald, Religionsdialogiska perspectiv p. 85; Alwall, Förutsättningar för religionsdialog, pp. 16 et seq.
} 
Christian, three Muslim, two Jewish, two Buddhist, and one each from the Bahái, Sikh, Hindu, Mandee, Alevi, Mormon community and Community of Forn Sed. ${ }^{21}$ The humanist association in Sweden is not, as in some other European countries, such as Norway, included in the council. ${ }^{22}$ In 2017 , ten of the representatives were men and eight were women. Some of the main aims for the council are to "promote and create conditions for inter-religious cooperation in Sweden, highlighting the role of religion to create goodwill and peace in the world and be a voice against religious hostility". 23

During the first five years, the council did not receive any financial support from the state and the costs were financially supported by the partaking religious organisations. However, in 2015 the government decided to assess the council with an annual grant for three years, a grant which was not extended in $2018 .^{24}$

Interfaith Council in Sweden has made some public declarations, for example about refugees in Sweden, and have been mentioned a few times in media, ${ }^{25}$ but cannot be seen as very influential in the public debate in Sweden. It is, however, clear that the Church of Sweden has had an important role in initiating and upholding the council, but has, in recent years, relinquished this position. ${ }^{26}$

\subsection{The Christian Council of Sweden}

The Christian Council of Sweden was, as mentioned above, established in 1992, emerging from the Swedish Ecumenical Council (established in 1932). In January 2020, 26 churches were part of the organisation, and a woman, Karin Wiborn, representing the free churches in Sweden, is secretary-general at the moment. Chairperson of the board is alternated between the member churches every year and the council is financed by the partaking churches.

The organisation has come to have an important role in IRD-activities in Sweden. It is, for example, one of the umbrella organisations that is part of the Swedish Interfaith Councils steering group and was, together with the Church

21 The Council have two Jewish representatives, which could be perceived as striking considering that there are not more than about 20,000 Jews in Sweden. The reason for this is the wish to have one representative each from the two major Jewish traditions in Sweden, namely the Orthodox and the Liberal. Forn sed is a neo-pagan organisation.

22 Interfaith Council in Sweden; interview with the coordinator Elias Carlberg (2017).

23 Internal documents, Interfaith Council in Sweden.

24 Interview with the coordinator Elias Carlberg (2017); e-mail correspondence with Karin Wiborn.

25 Interfaith Council in Sweden; internal documents from the Interfaith Council in Sweden.

26 E-mail correspondence with Karin Wiborn. 
of Sweden, an influential part during the formation process of the council. ${ }^{27}$ As the Swedish Ecumenical Council, they also had a role in the establishment of the umbrella organisation for the Orthodox and Eastern churches in the 1970s, and in the formation of the Swedish Authority for Government Support to Faith Communities. Lately, some of the churches have, however, withdrawn from the council, foremost due to economic reasons. ${ }^{28}$

\subsection{MUslim IRD}

As mentioned above, the Church of Sweden has historically initiated many interreligious activities with Muslims in Sweden. Later on, these activities came to be in cooperation with Muslim organisations. In a study carried out in 2018, more than $50 \%$ of Muslim communities stated that they had ongoing IRD-activities with Christian communities and a little less than $50 \%$ cooperated with other religious communities. A vast majority $(8 \circ \%)$ perceived these relations as positive. ${ }^{29}$ Muslim cooperation with other religious organisations have had a fast increase from the beginning of the 2010s, when only $30 \%$ of the Muslim communities stated that they participated in religious dialogue. ${ }^{30}$ Many Muslim organisations in Sweden are also, as mentioned before, part of Muslim umbrella organisations.

\subsection{The Church of Sweden and IRD}

The Church of Sweden have had, and still have, an important role in IRD-organisations and IRD-activities in Sweden. ${ }^{31}$ The Church have employed people responsible for interreligious dialogue in all the thirteen dioceses in Sweden, and since 2008 run a center for interreligious dialogue. The aim of the centre is to initiate and assist local interreligious activities and to impart knowledge and theological reflections on experiences of interreligious dialogue. ${ }^{32}$ Other influential IRD-organisations and IRD-activities upheld by the Church of Sweden are the network The Future Lives with Us, since 2000, which includes communities/parishes situated in multireligious suburbs in Sweden,

\footnotetext{
27 Religion i rörelse; Christian Council of Sweden.

28 Lecture by Max Stockman at the Swedish Authority for Government Support to Faith Communities.

29 Gardell, Moskéers och muslimska, pp. 30-33.

30 Borell/Gerdner, Cooperation or Isolation.

31 The Church of Sweden is also part of international IRD-organisations, such as the Council for a Parliament of the World's Religions.

32 Lööv Roos, Svenska kyrkans, p. 19.
} 
and Together for Sweden, aimed at youths. ${ }^{33}$ Others are Interreligious Praxis for Peace - A World of Neighbours, aiming at refugees, and Sisterhood \& Religious Meeting, which is a feminist interreligious network. ${ }^{34}$

A study from 2016 showed that $42 \%$ of the communities/parishes in the Church of Sweden were partaking in IRD-activities in 2016 and that $65 \%$ perceived this to be an important task for them in the future. ${ }^{35} 3 \%$ of the communities/parishes mentioned that they were part of IRD-organisations, which means that the Church of Sweden, with about 1,300 parishes, is part of about 40 local IRD-organisations. It is also important to remember that approximately $80 \%$ of the communities in the church are involved with refugee work, and one fourth perceive this as an interreligious activity. ${ }^{36}$

\subsection{The Swedish Authority for Government Support to Faith Communities}

One important actor to understand IRD-organisations and IRD-activities in Sweden is the Swedish Authority for Government Support to Faith Communities, established as a state authority in 2000, but originating in the 1970s. In Sweden, recognised faith communities can apply for financial support from this authority. ${ }^{37}$ The authority has, among its assignments, to facilitate faith communities' relations to the state and other parts of the society, and to establish interreligious dialogue, and is nowadays a driving force in many IRD-activities in Sweden. The authority has also been influential in the establishment of many of the aforementioned umbrella organisations. ${ }^{38}$

\subsection{Political Parties as IRD-Agents}

It is also worth mentioning that some political parties in Sweden have organised religious associations. One example of this is Religious Social Democrats of

33 Liljestrand, How Interreligious Buildings; Lööv Roos, Svenska kyrkans, p. 24; Svenska kyrkan; Fryshuset; Helgesson Kjellin, En bra plats att vara på; the "Future lives with us" is translated by the author from "Framtiden bor hos oss".

34 Svenska kyrkan; Lööv Roos, Svenska kyrkans; Sisterhood \& religious meeting is translated by the author from Systerskap \& religionsmöte.

35 The Church of Sweden has parishes in all parts of Sweden, which means that many of the parishes are active in areas where there are no other religious organisations to cooperate with (see also Liljestrand, How Interreligious Buildings, p. 161).

36 Nordin, Religionsdialog och interreligiös samverkan; Lööv Roos, Svenska kyrkans.

37 The aim of the grants is to: "Create opportunities for faith communities to pursue active and long-term religious activities in the form of worship, counselling, education and care" (Swedish Authority for Government Support). The Church of Sweden cannot apply for support from the authority.

38 Lund Liebmann/Galal/Nordin, Routes and Relations. 
Sweden, which is an association that is part of the Swedish Social Democratic Party - a party which during almost the whole zoth century were in government power in Sweden. ${ }^{39}$ They have about 2,500 members and 80 local groups. ${ }^{40}$ One of the aims for the association during the 2010 s has been interreligious dialogue and cultural diversity, and being part of the political establishment, they have the power to put this into action. While striving to assemble party members with religious belongings, whatever religion this may be, this group can also in itself be seen as an IRD-organisation. There is also an ecumenical Christian association for members of parliament, which has formally gathered members of parliament independently of political membership since 1904 .

Contemporary Local IRD

On a local level, we find several IRD-organisations and IRD-activities in Sweden. Some of these are 'independent' interreligious organisations, groups, or networks, while others are organisations that cooperate with local authorities in one way or another. I will start by giving two examples of local independent IRD-organisations, and then go further with presenting IRD-organisations that are part of local public institutions' IRD-organisations and activities, most known as IRD-councils.

\subsection{Independent IRD-Organisations}

Between 2010 and 2011, I did a study on local IRD-organisations and one of these was an independent IRD-group that had a long history in the area. It is a group which can be considered as quite a typical example for these kinds of local interreligious groups in Sweden. It started on behalf of the Church of Sweden in the 199os as a response to growing religious plurality in the area, and out of a wish to get to know more about each other. During some years at the beginning of the 200os, the group was inactive, but restarted in 2008; again on the initiative of the Church of Sweden, and the Church continued being responsible for upholding it for many years. Approximately 15 people with various religious backgrounds came to the monthly meetings, and did so foremost out of personal interest. However, some also participated as part of their employment. The group had chosen to let everyone who wanted join the

39 In Swedish: Socialdemokrater för tro och solidaritet (Social Democrats for faith and solidarity). Until 2011 the association was called Broderskapsrörelsen (the Brotherhood Movement).

Social Democrats for Faith and Solidarity. 
group; this meant, for example, that Scientologists came to participate, leading to others leaving the group. ${ }^{41}$

From the start, focus for the group was to secure the future for religion in the Swedish society by working together. Later on, focus came to be on what they had in common, talking at the meetings about things like prayer, worship and how to understand God. The meetings were characterised by a desire for consensus and finding similarities, and things that were difficult to agree upon were manifestly avoided. Occasionally the group interacted with the municipality, for example, by arranging seminars at the library in the city, where they presented the different religions to which they belonged. ${ }^{42}$

Another independent, in Sweden well-known, local IRD-organisation is God's House Fellowship from 2009, located in Fisksätra, a suburb of Stockholm. This organisation is quite different from the former one, and the aim of the organisation is to construct a building that local communities of the Church of Sweden, the Catholic Church and the Muslim community can share, but have separated rooms of worship. The aim of the building is to express togetherness, but without mixing religions. To secure the joint responsibility for it, various interreligious meetings have taken place. These have not been without problems and tensions, and in 2020 the building is still not finished. ${ }^{43}$

\subsection{IRD-Councils}

During the last 10 years, several IRD-organisations that are part of, or closely related to, public institutions or public authorities in Sweden, have been established in Sweden. ${ }^{44}$ Some of these are reconstructed independent IRD-organisations, others are initiated by local authorities, often with support from the aforementioned Swedish Authority for Government Support to Faith Communities. Today about 20 such local IRD-councils can be found in Sweden. The reasons behind these councils are often a desire for social cohesion, and the local authorities wish to also include religious organisations in this work. ${ }^{45}$ This was expressed by an official at a municipality in the following

41 The reassignment of these persons had to do with that they participated in the group as of the part of their employment, and their bishops did not allow them to continue to participate when scientologist joined the group.

42 See also Nordin, Secularization, Religious Plurality and Interreligiös a gruppers.

43 Liljestrand, How Interreligious Buildings and Case Study 4: The Church Area of Fisksätra; Lööv Roos, Svenska kyrkans, p. 15.

44 Axelson/Hansson/Sedelius, Från privatsak till politiskkraft, p. 2; Nordin, Interreligiösa gruppers.

45 Axelson/Hansson/Sedelius, Från privatsak till politiskkraft, p. 5; Nordin, Secularization, Religious Plurality; Nordin, Interreligiösa gruppers. 
way: "the municipality felt a need to form a group that consisted of different communities, and then work to increase understanding and respect for each other's similarities and differences". 46 These councils, I would argue, can be seen as having mostly social functions and little religious purpose. ${ }^{47}$

\subsection{Other Local IRD-Agents and IRD-Activities}

In order to understand local IRD-organisations and IRD-activities in Sweden, it is important to include the work done by so called educational associations. These associations have a long and important history in Sweden, with the aim to promote citizens' education outside the general school system. They are financially supported by the state, but are initiated and taken care of by the citizens themselves. In some of these, the task to promote inclusion and dialogue has led to various IRD-activities, for example in the aforementioned God's House Fellowship, that have close cooperation with the umbrella organisations for the Orthodox and Eastern churches and Muslim communities in Sweden.

What we also have to take into consideration are the IRD-activities done in relation to the welfare system. In Sweden, many hospitals host interreligious "chaplaincies", and prison welfare guarantees the possibility to practise religion, which at prisons is taken care of by interreligious boards. ${ }^{48}$ The universities are not, however, as in other European countries, a place where influential, if any, IRD-activities take place. Nevertheless, most of the universities do have different kinds of chaplaincy rooms for prayer and religious meetings. ${ }^{49}$ Other places where local IRD-activities take place in Sweden are cemeteries, church choirs, and in connection to catastrophes, when people from different religious backgrounds gather to grieve. ${ }^{50}$

46 Translated by the author from: "känt behov av att bilda en grupp som bestod av olika samfund och sen jobba för att öka förståelse och respekt för varandras likheter och olikheter". Nordin, Interreligiösa gruppers, p. 41.

47 See also Ipgrave, Religious Thinking, p. 253.

48 See also Fridolfsson/Elander, Faith-based Organizations and Welfare State.

49 Hoeg/Christiansen/Kühle/Nordin, Rooms of Silence at three universities.

50 In Sweden, with the exception of two cities, Stockholm and Tranås, the Church of Sweden have the responsibility for cemeteries, but they must include burial places for people with what every religion they uphold. 
What we find in Sweden today is one national and various local IRDorganisations. If we include ecumenical and umbrella organisations, however, we find at least ten national IRD-organisations. The establishment of IRD-organisations in Sweden is, however, quite a new phenomenon, and the institutionalisation of many of these has not been realised until the 2oros. There is also a multitude of different local IRD-activities going on and some national ones, which often are initiated and upheld by the Church of Sweden. The IRD-activities have a longer history in Sweden, and many of them started already in the 1960s.

How does the socio-cultural context relate to the establishment and upholding of IRD-organisations and IRD-activities in Sweden? I mean that there are two major socio-cultural areas that have an influence, and these are the increased religious plurality in Sweden during the last decades due to immigration, and the ongoing processes of secularisation together with a secular constitution.

\subsection{Increased Religious Plurality}

The increased religious plurality in Sweden during the last decades, foremost due to immigration from the middle of the 2oth century and onwards, is, I would argue, probably the most important reason for the establishment of IRD-organisations and for IRD-activities in Sweden. Religious plurality is the presumption for all IRD, but in the Swedish case this happened quite late in history; even though we find ecumenical organisations already from the 1930s, and religious umbrella organisations from the 1970s, the first national interreligious organisation, the Swedish Interreligious Council, was not established until 2010, which is also the case for local IRD-councils. This can seem strange since religious plurality in Sweden started already in the 1950s. That local independent IRD-organisations and local IRD-activities have an older history, and are far more common than national organisations and initiatives, may be traced back to the late history of religious pluralisation. It is at a local level where religious plurality takes place and is lived, and many independent IRD-organisations and local IRD-activities started as a direct response to this. That there is a historic lag for these to reach a national level may be explained by the second socio-cultural area in Sweden influencing IRD, namely a secularised society and a secular state, which I will come back to later.

Another explanation for the late history of IRD-organisations, but an earlier history and a broader occurrence of ecumenical and umbrella organisations, can be that the religious plurality in contemporary Sweden is still not in any 
sense equal. The Church of Sweden has had, and still has, a dominant role in the country, which influences the IRD-organisations and IRD-activities in Sweden. The Church of Sweden has, in comparison with the other religious organisations, an advantage when it comes to size, establishment, leadership maintenance, financial resources, and access to facilities. This affects the possibilities for equality in the cooperation between the religious organisations in Sweden, and thereby aggravates the establishment and upholding of IRD-organisations and IRD-activities. ${ }^{51}$

\subsection{A Secularised Society and the Secular State}

The conditions for IRD-organisations and IRD-activities in Sweden are highly influenced by a society strongly characterised by secularisation together with the secular state. This can, for example, be a reason for the late history of IRD-organisations in Sweden. But, I would argue, it could also be the reason for the establishment of these organisations and for IRD-activities. One example of how secularisation can be a reason behind IRD-organisations and IRD-activities in Sweden, is, for instance, how independent local IRD-organisations and the Interfaith Council in Sweden have among their aims to uphold and secure religion in Sweden. It can, as in the Spanish case, be seen as a "window of opportunity" for the Church of Sweden, and as a resource for the other less influential religious organisations. ${ }^{52}$

The secular state as an explanation for IRD-organisations and IRD-activities in Sweden can be found in the aforementioned secularity in Sweden, characterised by a pragmatic secularism. When the Swedish society no longer only faces processes of secularisation, but also an increase of religious organisations, the 'taken for granted' decrease of religion is challenged. This leads to the idea of a secular state being tested. Together with the aforementioned inequality between religious organisations, with the Church of Sweden having in many ways a dominant position, the reaction from a pragmatic secular state can be traced to the establishment of IRD-organisations and IRD-activities. ${ }^{53}$ The state, in many ways, promotes the IRD-organisations and IRD-activities, for example by The Swedish Authority for Government Support to Faith Communities, by initiating local IRD-councils, by the state-funded educational associations, having political IRD-associations and IRD-government groups,

51 See also Liljestrand, How Interreligious Buildings; Nordin, Secularization, Religious Plurality and Interreligiösa gruppers; Gärde, Shrinking Religious Communities, p. 15; Palmblad, Det nya landet, pp. $5^{2-54}$.

$5^{2}$ Cf. Griera, The Many Shapes of Interreligious Relations in Contemporary Spain.

53 See Griera/Nagel, Interreligious Relations, p. 303. 
and also in IRD-activities taking place in the welfare system. The aim of this support is, however, not foremost religious, but social; and this fits nicely into an idea of a secular state. ${ }^{54}$

\section{Conclusion}

Therefore, what we can see is that the positioning of Sweden in The Swiss Metadatabase of Religious Affiliation in Europe (SMRE) as Protestant-Pluralized to some extent also explains IRD within the country. The majority church, The Church of Sweden (Protestant), have influenced IRD-organisations and IRD-activities over a long period of time, and religious plurality in Sweden makes it possible, and maybe also desirable, to establish IRD-organisations and implement IRD-activities. However, secularisation and secularity are other socio-cultural factors shown to explain IRD in Sweden. There are certainly more socio-cultural factors, such as a historically stable, democratic, and unitary state (where Sweden differs from many other European countries), securitisation of Islam, and global processes, that most certainly also influence IRD-organisations and IRD-activities in Sweden. ${ }^{55}$ With the knowledge we have until now, it is, however, not possible to say how these later areas affect IRD in Sweden. More research is needed to continue with these latter assumptions, and also to be able to analyse in greater depth how religious plurality, secularisation, and a secular state relate to IRD in Sweden.

\section{Biography}

$\mathrm{PhD}$ Magdalena Nordin is a Sociologist of Religion whose research areas include religion and migration, religion in health care and interreligious dialogue. She works as associate professor at University of Gothenburg, Sweden. She is currently heading a four-year research project at Lund University on the Syriac Orthodox Church in Sweden and is part of a research project about Pentecostal immigrants in Sweden.

54 Irene Becci (Becci, Religious Superdiversity and Gray Zones) suggest the concept gray zone to highlight these complex and blurred relations between religion and secularity; see also Ipgrave, Religious Thinking, p. 253; Körs, How Religious Communities Respond.

55 See also Galal, Making space for faith; Prideaux, Understanding Neighbourhoods. 


\section{Bibliography}

Ahlstrand, Kajsa: Religionsdialog, in: Ingvar Svanberg/David Westerlund (eds.): Religion i Sverige. Stockholm: Dialogos Förlag, 2008.

Alwall, Jonas: Förutsättningar för religionsdialog i dagens svenska samhälle, in: Svensk Teologisk Kvartalskrift 75 (1/1999).

Aronson, Torbjörn: Ett nytt karismatiskt landskap i Sverige: Trosrörelsen, samfundsoberoende församlingar, migrantförsamlingar, anglosaxiska nätverk och många andra - en församlingsöversikt. Uppsala: Areopagos, 2016.

Aneer, Gunnar: Dialoger mellan muslimer och kristna, in: Ingvar Svanberg/David Westerlund (eds.): Blågul islam? Muslimer i Sverige. Nora: Nya Doxa, 1999, pp. 249-262.

Axelson, Tomas/Hansson, Ulf/Sedelius, Thomas: Från privatsak till politiskkraft? Borlänges interreligiösa råd och förväntningar på religion som resurs i lokalsamhället, Report nr 7, Interkulturellt utvecklingscentrum Dalarna (IKUD), 2018.

Becci, Irene: Religious Superdiversity and Gray Zones in Public Total Institutions, in: Journal of Religion in Europe 11 (2-3/2018), pp. 123-137.

Borell, Klas/Gerdner, Arne: Cooperation or Isolation? Muslim Congregations in a Scandinavian Welfare State: A Nationally Representative survey from Sweden, in: Review of Religious Research 55 (4/2013).

Bäckström, Anders: Religion mellan det privata och det offentliga - om religion och välfärd, in: Stenström, Hanna (ed.): Religionens offentlighet. Om religionens plats i samhället, Stockholm: Artos \& Norma bokförlag, 2013.

Galal, Lise: Making space for faith. Interfaith initiatives in Denmark, in: John Fahy/ Jan-Jonathan Bock (eds.): The interfaith Movement. Mobilising religious Diversity in the 21st Century. Abingdon/New York, NY: Francis \& Taylor, 2020, pp. 87-103.

Fridolfsson, Charlotte/Elander, Ingemar: Faith-based Organizations and Welfare State Retrenchment in Sweden: Substitute or Complement?, in: Politics and Religion 5 (3/2012), pp. 634-654.

Gardell, Mattias: Moskéers och muslimska församlingars utsatthet och säkerhet i Sverige 2018; Centrum för mångvetenskaplig forskning om rasism (CE MFOR), Uppsala universitet, 2018.

Griera, Mar: The Many Shapes of Interreligious Relations in Contemporary Spain: Activism, Governance and Diplomacy, in:JRAT 6 (2/2020), pp. X-X.

Griera, Mar/Nagel, Alexander-Kenneth: Interreligious Relations and Governance of Religion in Europe, in: Social Compass 65 (3/2018), pp. 301-311.

Gustafsson, Berndt: Lokal ekumenik-symbolakt eller praktisk problemlösning, Forskningsrapport, nr 58, Religionssociologiska institutet, 1969.

Gärde, Johan: Shrinking Religious Communities and Thriving Interreligious Social Work in Postsecular Sweden, in: Journal of Religion \& Spirituality in Social Work: Social Thought 34 (1/2015), pp. 1-23. 
Helgesson Kjellin, Kristina: En bra plats att vara på: en antropologisk studie av mångfaldsarbete och identitetsskapande inom Svenska kyrkan. Skellefteå: Artos \& Norma, 2016.

Hoeg, Ida Marie/Christiansen, Henrik Reintoft/Kühle, Lene/Nordin, Magdalena: "Rooms of Silence at three universities in Scandinavia", in: Sociology of Religion: A Quarterly Review 80 (3/2019), pp. 299-322.

Ipgrave, Julia: Concluding Chapter: Religious Thinking in the Negotiation and Maintenance of Pluralism in Practice, in: Julia Ipgrave (ed.): Interreligious Engagement in Urban Spaces: Social, Material and Ideological Dimensions. Cham: Springer, 2019, pp. 251-26o.

Ipgrave, Julia: Meeting Acting and Talking Together in Three East London Boroughs, in:Julia Ipgrave/Thorsten Knauth/Anna Körs/Dörthe Vieregge/Marie von der Lippe (eds.): Religion and Dialogue in the City: Case Studies on Interreligious Encounter in Urban Community and Education. Münster/New York, NY: Waxmann Verlag, 2018, pp. $85^{-114}$.

Körs, Anna: How Religious Communities Respond to religious Diversity. From Interreligious Dialouge to Interreligious Relations, Contacts and Networks, in: Julia Ipgrave/Thorsten Knauth/Anna Körs/Dörthe Vieregge/Marie von der Lippe (eds.): Religion and Dialogue in the City: Case Studies on Interreligious Encounter in Urban Community and Education. Münster/New York, NY: Waxmann Verlag, 2018, pp. $23-54$.

Liljestrand, Johan: Case Study 1: Maintaining and Transforming Bridging Capital in a Swedish Interreligious Youth Project, in: Julia Ipgrave (ed.): Interreligious Engagement in Urban Spaces: Social, Material and Ideological Dimensions. Cham: Springer, 2019, pp. 29-38.

Liljestrand, Johan: Case Study 4: The Church Area of Fisksätra, Stockholm, in:Julia Ipgrave (ed.): Interreligious Engagement in Urban Spaces: Social, Material and Ideological Dimensions. Cham: Springer, 2019, pp. 137-144.

Liljestrand, Johan: How Interreligious Buildings Influence Interreligious Neighbourhood Relations: The Case of the God's House Project in a Stockholm Suburb, in: Julia Ipgrave/Thorsten Knauth/Anne Körs/Dörthe Vieregge/Marie von der Lippe (eds.): Religion and Dialogue in the City: Case Studies on Interreligious Encounter in Urban Community and Education. Münster/New York, NY: Waxmann Verlag, 2018, pp. 159-180.

Lund Liebmann, Louise/Galal, Lise Paulsen/Nordin, Magdalena: Routes and Relations in Scandinavian interfaith forums: Governance of Religious Diversity by States and Majority Churches, in: Social Compass 65 (3/2018), pp. 329-345.

Lööv Roos, Peter: Svenska kyrkans interreligiösa sammanhang. Report, Church of Sweden, 2016.

Nielsen, Jørgen/Otterbeck, Jonas: Muslims in Western Europe (Fourth edition). Edinburgh: Edinburgh University Press, 2016. 
Nordin, Magdalena: "Secularization, Religious Plurality, and Position: Local InterReligious Cooperation in Contemporary Sweden", in: Social Compass 64 (3/2017), pp. 388-403.

Nordin, Magdalena: Religionsdialog och interreligiös samverkan i Svenska kyrkans församlingar 2016. En kvantitativ studie, Report, Church of Sweden, 2017.

Nordin, Magdalena: Vad vi vet och inte vet om kristna migranter i Sverige, in: Anders Aschim/Olav Hovdelien/Helje Kringlebotn Sødal (ed.): Kristne migranter i Norden. Kristiansand: Portal forlag, 2016, pp. 21-38.

Nordin, Magdalena: Interreligiösa gruppers samarbete med kommuner i Sverige, in: Tidsskriftet Politik 17 (4/2014), pp. 37-44.

Palmblad, Marika: Det nya landet - kristen och muslimsk dialog som utmaning och möjlighet. Lund: Arcus förlag, 2005 .

PEW 2019. How do European Countries Differ in Religious Commitment, https://www. pewresearch.org/fact-tank/2018/12/05/how-do-european-countries-differ-inreligious-commitment (date of last access: 10.08.2020).

Prideaux, Melanie: Understanding Neighbourhoods as Multifaith Spaces, in: Religions 10 (2019), pp. 1-12.

Religion i rörelse, Yearbook, The Swedish Authority for Government Support to Faith Communities, 2019.

Roald, Anne-Sofie: Religionsdialogiska perspektiv. En fallstudie av en dialoggrupp i södra Sverige, in: Mikael Stenmark/David Westerlund (ed.): Polemik eller dialog? Nutida religionsteologiska perspektiv bland kristna och muslimer. Nora: Nya Doxa, 2002, pp. 83-97.

Sorgenfrei, Simon: Islam i Sverige: de första 1300 åren, The Swedish Authority for Government Support to Faith Communities, 2018.

Willander, Erika: Sveriges religiösa landskap: samhörighet, tillhörighet och mångfald under 200o-talet, ssT: skriftserie, Nr. 8, The Swedish Authority for Government Support to Faith Communities, 2019.

\section{Other}

Christian Council of Sweden, https://www.skr.org/ (date of last access: 13.02.2020).

E-mail correspondence with Karin Wiborn, President of the Interfaith Council in Sweden, 22.08.2019.

Fryshuset. Together for Sweden, https://www.fryshuset.se/verksamhet/tillsammansforsverige/in-english (date of last access: 14.02.2020).

Interfaith Council in Sweden, http://interreligiosaradet.se/medlemmar/ (date of last access: 02.14 .2020$)$.

Internal documents, Interfaith Council in Sweden, belong to the author. 
Interreligious Praxis for Peace - A World of Neighbours, https://www.svenskakyrkan. se/migration/envarldavgrannar (date of last access: 14.02.2020).

Interview with coordinator Elias Carlberg, Interfaith Council in Sweden, 11.05.2017.

Kammarkollegiet, The Legal, Financial and Administrative Services Agency, https:// www.kammarkollegiet.se/ (date of last access: 10.08.2020).

Lecture by Max Stockman, officer at the Swedish Authority for Government Support to Faith Communities, 23.05.2019.

Social Democrats for Faith and Solidarity, https://trosolidaritet.se (date of last access: 14.02.2020).

Statistics, Church of Sweden 2020, https://www.svenskakyrkan.se/statistik (date of last access: 17.02.2020).

Svenska kyrkan. The Future Lives with Us, https://www.svenskakyrkan.se/framtidenborhososs/defaultaspxid584694 (date of last access: 14.02.2020).

Swedish Authority for Government Support to Faith Communities, http://www.sst.a.se/ uppdrag.4.15272bfd13b817fbae130oo.html (date of last access: 17.08.2019).

Swiss Metadatabase of Religious Affiliation in Europe, https://www.smre-data.ch (date of last access: 03.05.2019). 